Original Research Paper

\title{
Biochemical Indicators and Nutritional Value of Horsemeat Infected by Parascaridosis and Sampled from the Surrounding Areas of Semipalatinsk Nuclear Test Site, Kazakhstan
}

\author{
${ }^{1}$ Shyngys Suleimenov, ${ }^{1}$ Sergazy Duyssembaev, ${ }^{1}$ Ainur Serikova, \\ ${ }^{1}$ Abdrakhman Baygazanov, ${ }^{1}$ Ainur Koygeldinova and ${ }^{2} *$ Zhanibek Yessimbekov \\ ${ }^{1}$ Department of Veterinary Science, Agrarian Faculty, Shakarim University, Semey City, Kazakhstan \\ ${ }^{2}$ Department of Technological Equipment and Mechanical Engineering, Engineering Faculty, \\ Shakarim University, Semey City, Kazakhstan
}

\author{
Article history \\ Received: 22-12-2020 \\ Revised: 08-02-2021 \\ Accepted: 09-02-2021 \\ Corresponding Author: \\ Zhanibek Yessimbekov \\ Department of Technological \\ Equipment and Mechanical \\ Engineering, Engineering \\ Faculty, Shakarim University, \\ Semey City, Kazakhstan \\ Email: zyessimbekov@gmail.com
}

\begin{abstract}
Due to high prevalence of the Parascaris equorum among horses, the effect of Paracardiosis infestation on nutritional and biological values of meat is required. In an effort to analyze the radionuclides contents, biochemical parameters and biological value of horsemeat collected from different areas of Semipalatinsk Nuclear Test Site (SNTS) of Kazakhstan. The prevalence of parascaridosis was performed following standard protocols. Organoleptic properties, chemical composition, amino acids composition, vitamin contents of meat collected from zone of extreme radiation risk, zone of maximum radiation risk, zone of increased radiation risk and zone of minimum radiation risk were appraised following previously reported standard assays. $\mathrm{pH}$ indicators, reaction to peroxidase enzyme, formolic reaction and bacterioscopy of fingerprints were done. Contents of essential minerals were also compared. Specific radioactivity of radionuclides in meat were Am-241 less than $0.5 \mathrm{~Bq} / \mathrm{kg}$, Cs-37 from 0.5-3.99 Bq/kg and Pu-239/240 from 0.0003-0.056 Bq/kg. The chemical composition showed that the content of protein varies from $14.2-18.7 \%$ and fat from $14.2-17.2 \%$. In addition, the content of amino acids, fatty acids and vitamins were evaluated. Among the mineral composition, iron content was from 2705-3012 $\mu \mathrm{g} / 100 \mathrm{~g}$, copper from 178.0-195 $\mu \mathrm{g} / 100 \mathrm{~g}$ and zinc from $27.7-29.5 \mu \mathrm{g} / 100 \mathrm{~g}$, depending on the remoteness of areas from the SNTS.
\end{abstract}

Keywords: Horsemeat, Radionuclide, Semipalatinsk Test Site, Mineral, Vitamins, Amino Acids, Fatty Acids

\section{Introduction}

Nuclear tests are associated with severe health hazards predominantly cancers as a result of radiations and nuclear waste (Grosche et al., 2015). The Semipalatinsk Test Site (STS) also called "polygon" located in the north Kazakhstan was extensively used as nuclear test site by Soviet union (Logachev, 2000). The problem of environmental safety to the Republic of Kazakhstan is directly related to the radiation situation in the territory of the former Semipalatinsk Test Site (STS) (Grosche, 2002; Purvis-Roberts et al., 2007). Keeping in view the health hazards associated with the STS, UN General Assembly has recognized the seriousness of the situation and has adopted three resolutions on the issue of assistance to the region (Grosche, 2002; Zhumadilov et al., 2013; Kakimov et al., 2016). Despite the measures taken within the framework of individual state, sectoral and regional programs, international assistance are limited in solving the problems of the region. Previous studies are essentially fragmentary and inefficient to provide sufficient data for monitoring the region and subsequent adequate decisions (Levine et al., 1990).

Nowadays horsemeat is extensively used in East and Europe owing to the diversity of benefits associated with its consumption (Lee et al., 2007; Belaunzaran et al., 2015). Horsemeat has got high nutritional values and special organoleptic properties (Duyssembaev et al., 2016). Horsemeat is an easily digestible meat and contains a large amount of 
complete protein, optimally balanced amino acid composition. Horse fat occupies an intermediate position between animal and vegetable fats and has choleretic effects. Further, it lowers blood cholesterol level, regulates metabolism, rich in essential micro elements, vitamins, essential fats and is integral part of diet therapy against obesity (Lorenzo et al., 2014). In the West, a number of dishes including sausages, smoked meats and canned food are prepared from it and is considered a mandatory component in the preparation of higher varieties of foods. Subsequently, the demand for horse fresh meat, frozen and chilled meat is steadily increased on the world market.

Parascaridosis is an acquired disease, with most prevalnce in colts and disease manifested by delayed growth and exhaustion, reduced appetite, alternating diarrhoea and constipation and colic attacks. The causative agent of the disease is considered to be the nematode Parascaris equorum of the Ascarid genus (Demidchik, 2001; Sidorkin, 2007). Most horses are infected with helminths, the most common of which are Parascaris eguorum, Oxyurus equi and Strongyloides westeri (Miller et al., 2017). Among the most prevalent horse helminthes include Parascaris equorum in some regions of Russia reaches 90-100\%. Whereas, other helminthes parascaridosis, oxyurosis and strongylyatosis were also reported by researchers in Transbaikal area of BAM (in Bounty district of Buryatia and in Kalar district of Chita region) (M). According to (Ponomarev, 1997), in the Altai farms the degree of horse invasion by parascarids is $78.4 \%$ whereas, another study reported the invasion of Parascaris equorum in Volgograd Region as high as 60.1\%. In 20072008, the parasitic infestation in horses among different farms of Ukraine were predominantly by Anoplocephalidae sp., like Parascaris equorum, Strongylidae sp., Oxyuris equi, Draschia megastoma, Habronema muscae, Setaria equina, Dictyocaulus arnfieldi (Berezovsky and Galat, 2008). In Akbuzat racetrack (Bashkiria) about $89 \%$ of horses were reported to have several types of intestinal nematodes including parascarides, oxyuryses and strongylates (Zotova, 2011). Based on the above facts, the current study was designed to appraise the nutritional and biological values of horsemeat collected from Semipalatinsk Test Site (STS) of Kazakhstan.

On the basis of the goal, we defined the following objectives:

1. To determine the organoleptic and biochemical parameters of horsemeat in case of parascaridosis of horses under the conditions of the former STS

2. To identify the differences in chemical, biochemical, amino acid, fatty acid content, vitamins and minerals in the meat of horses with parascaridosis in the conditions of the former STS
For this region, cattle breeding is practically the main type of activity. Uncontrolled agricultural activities on the territory of Semipalatinsk test site is one of the most important problems, since the lands are used for cattle grazing. There is no regulated economic activity on the territory of the STS and adjacent territories. Unauthorized activities of economic entities are observed.

\section{Materials and Methods}

The research work was carried out during 2018-2019 in the test regional laboratory of engineering profile "Scientific Center of Radio Ecological Research" and in the laboratory of the "Veterinary" Department of the Shakarim State University of Semey, in the Bodene, Beskaragay, Shynkozha, Sagyr and Zhantikei villages. Radiometric control of the studied territories. The dose rate of gamma radiation, the flux density of beta particles and the flux density of alpha particles were determined according to the current (GOST 26305-84, 1984; GOST 26306-84, 1984; GOST 26307-84, 1984). Measurements of the Equivalent Equilibrium Volume Activity (EEVA) of radon and thoron were carried out in the open area and in the air of residential premises of the studied territories. For this purpose radiometer-dosimeter RKS-01-SOLO, Dosimeter-radiometer MKS-AT6130, Radon monitor RAMON-02 were used. Radiometer-dosimeter RKS01-SOLO device is designed for integrated radiation monitoring of the environment, workplaces, installations and vehicles. Dosimeter-radiometer MKS-AT6130 is used to control radioactive contamination of work surfaces, skin, clothing and personal protective equipment. Whereas, Radon monitor RAMON-02 and its daughter decaproducts RAMON-02 is highly sensitive express measurement dosimeter of the volume activity of radon and thoron daughters. They are used for determination of the phase and equilibrium coefficient of radon, thoron, value of "latent energy" of radon and thoron daughters.

\section{Samples Collection and Analysis}

Samples were collected from muscles at the incision against the 4th and 5th cervical vertebrae; from muscles in the area of the shoulder blade; from thick parts of the thigh muscles. Sampling collection and evaluations were carried out using previously reported GOST 17.4.3.01-83 Nature Protection protocols. For Soils sampling GOST 27262-87, Feed of plant origin, sampling methods; ST RK GOST R 51592-2003 Water were used. General requirements for sampling; ST RK 1545-2006 Radiation control. 


\section{Gamma-Spectrum Meat Analysis}

Meat samples were cut into small pieces and chopped using an electric meat grinder and placed in a Marinelli vessel. Gamma-spectrum analysis was performed on a gamma spectrometer with an electro-cooled germanium coaxial detector following standard protocol (GOST 26307-84, 1984).

\section{Helminthicological Studies}

Most helminths parasites in animals are released into the external environment through the gastrointestinal tract in the form of eggs, larvae and body fragments. Therefore, helminthological studies are the main methods to diagnose helminths, including parascarides. Methods of helminthocoprologic research are divided into qualitative methods, which allow to determine what types of helminths the animal is infected with and quantitative methods, which allow to judge about the intensity of invasion. This method includes the Darling Method.

\section{The Darling Technique}

Using this method, a small amount of faeces (1-2 g) is stirred in a glass with $20-30 \mathrm{~mL}$ of water. The mixture is filtered into centrifuge tubes and centrifuged for 1-2 min. Subsequently, the upper layer of liquid is drained and a mixture of equal parts of glycerine and sodium chloride is added to the sludge. The mixture in the tubes is shaken and centrifuged again. The eggs that have floated up to the surface are removed together with a film of suspension by a wire loop, shaken onto a slide glass and analyzed microscopically. This is followed by helminthological dissection of the small intestine with the following lavage of the intestinal tract contents. Parascalides which are large helminths are observed visually. Helminths are collected, counted and if necessary for storage, fixed in Barbagallo solution (3\% formalin solution in isotonic sodium chloride solution (Lebedev and Usovich, 1976).

\section{Organoleptic, Biochemical and Bacteriological Studies}

To evaluate meat quality, organoleptic, biochemical and bacteriological methods were used. The freshness of the meat was assessed via fluorescent method. The luminescent method is the simplest and most accurate method. Briefly, $10 \mathrm{~g}$ of meat was grinded, placed in a flask and filled with $50 \mathrm{~mL}$ of distilled water and insisted for $10 \mathrm{~min}$ with periodic shaking. Then it was passed through a double humidified filter and in a Petri dish was placed in the viewing chamber of the philinoscope "Filin" (GOST 23392-2016, 2016). Smell of the tested samples was organoleptically determined. Then a clean knife was used to make the incision and immediately determine the smell in the deep layers. Particular attention was paid to the smell of muscle tissue adjacent to the bone (GOST 7269-79, 1979). For determination the consistency, a sample of meat was gently pressed a finger to form a hole and its smoothness was observed (GOST 9959-91, 1991).

\section{Determination of Amino Acid, Fats and Moisture Contents}

Determination of amino acids, fatty acid composition and vitamins contents was carried out using a liquid chromatograph SHIMADZU LC-20 Prominence, (Japan) with fluorometric and spectrophotometric detector. A SUPELCO C18 chromatographic column (5 $\mu \mathrm{m}$ diameter; Sigma-Aldrich, St. Louis, USA) with a surface area of $200 \mathrm{~m} 2 / \mathrm{g}$ was used. Chromatographic analysis was performed under a linear gradient with eluent flow rate of $1.2 \mathrm{~mL} / \mathrm{min}$ and a column heated in an oven to $400^{\circ} \mathrm{C}$. Amino acids were detected by fluorometric and spectrophotometric detectors at 246 and $260 \mathrm{~nm}$ following acidic hydrolysis and treatment with a phenylisothiocyanate solution in isopropyl alcohol to give phenylthiohydantoins. Whereas, the content of macro and microelements according to (GOST 26931-86, 1986; GOST 26934-86, 1986).

Partial helminthological dissection of the small intestine was performed with the following washing of the intestinal tract contents by alternating flushes. Parascarids are large helminths and they are visually seen. Helminths were collected, counted and, if necessary for storage, fixed in Barbagallo's solution (3\% formalin solution).

\section{Statistical Analysis}

Each experiment was performed in triplicate and values were expressed as mean \pm SEM of three independent observations. All experiments on live animal in our experience were performed in accordance with relevant guidelines and regulations (Russian regulations (Order of the Ministry of Health of the USSR 155 of 12.08.1977). The experiments and animal care protocol were approved by the animal welfare committee of Shakarim University of Semey.

\section{Results}

Parascaris is widespread in horses and has a natural focus. In isolated areas, the invasion occurs for many years and has a permanent appearance. A specific role in the spread of nematodes Parascaris equorum in horses is caused by a low management culture of horse breeding, lack of systematic, planned, preventive, therapeutic and veterinary-sanitary measures and change of pastures. No special studies on the epizootology of $P$. equorum nematodes in horses and veterinary and sanitary 
evaluation of slaughter products, in particular, the quality of horse meat are not carried out in the conditions of the former STS and its adjacent territories. Horse parascariasis in the conditions of the former STS and adjacent territories significantly affects the development of horse breeding. According to (Suleimenov et al., 2019), the radio-ecological situation in the region is considered alarming, in these places gastrointestinal parasites find their favorable conditions for their development. Parascaridae by migrating, growing in the body of horses significantly affect the biological value of horse meat.

\section{Radiometric Values of the Studied Territories}

EDR levels in the zone of extreme radiation risk, of maximum radiation risk, increased radiation risk and zone of minimum radiation risk were observed to be $0.32 \pm 0.05$, $0.17 \pm 0.03,0.14 \pm 0.03$ and $0.1 \pm 0.02 \mu \mathrm{Sv} / \mathrm{h}$ respectively as shown in (Table 1). Likewise, the alpha-particle flux density was $0.2 \pm 0.2$ to $3.2 \pm 0.2 \mathrm{part} / \mathrm{min}^{*} \mathrm{~cm}^{2}$ in the zone of extreme radiation risk, $1.3 \pm 0.04 \mathrm{part} / \mathrm{min} * \mathrm{~cm}^{2}$ in the zone of maximum radiation risk and $0.5 \pm 0.6 \mathrm{parts} / \mathrm{min} * \mathrm{~cm}^{2}$ in the zone of increased radiation risk. Further, measured values of beta-particles flow density in all investigated points were $8.6 \pm 0.08 \mathrm{parts} / \mathrm{min}^{*} \mathrm{~cm}^{2}$ in the zone of extreme radiation risk, $5.4 \pm 0.04$ parts $/ \mathrm{min}^{*} \mathrm{~cm}^{2}$ in the zone of maximum radiation risk and $3.5 \pm 0.6$ parts $/ \mathrm{min}^{*} \mathrm{~cm}^{2}$ in the zone of increased radiation risk. Equivalent Equilibrium Volume Activity (EEVA) of radon in all points of the study were $<5.2 \mathrm{~Bq} / \mathrm{m}^{3}$. The EEVA of radon ranges from 59 to $128 \mathrm{~Bq} / \mathrm{m}^{3}$. According to the results of the studies it was established that the volume activity of radon and thoron in the atmospheric air did not exceed the values of the allowable average annual volume activity for the population, established by hygienic standards and is $200 \mathrm{~Bq} / \mathrm{m}^{3}$.

\section{Prevalence of Parascaridosis}

The prevalence of parascaridosis in the tested horses aged 1-4 years in East Kazakhstan Region was $26-100 \%$. This has significant effect to the health of horses and quality of meat. According to our investigation in fall period in average $56.85 \%$ of horses had parascaridosis invasion, whereas, in winter period $23.65 \%$, in spring $35.35 \%$ and in summer period it is $47.05 \%$ (Fig. 1).

\section{Organoleptic Evaluation of Horsemeat in Case of Parascaridosis}

On visual inspection, meat from the zone of minimal radiation risk showed that the state of the cut site is uneven, intensively impregnated with blood. The degree of exsanguination is good, blood was absent in muscles and blood vessels, small vessels under the hymen and abdomen was not translucent. Hypostases were absent, lymph nodes were unchanged at the cut of light gray color. The color of meat was red with the crust of drying and the surface of meat does not leave a damp spot on the filter paper. Meat was of dense consistency with characteristic smell. The color of fat was white with a yellowish tint with specific smell and consistency is soft and elastic. Tendons were dense and the surface of the joints was observed to be smooth and shiny.

The horsemeat collected from the zone of maximum radiation risk was evenly impregnated with blood at the state of the cut site and the degree of exsanguination was good. On the side of pleura and peritoneum the vessels were poorly exposed, hypostases were absent and lymph nodes were within the norm. Whereas, meat collected from animals of this zone was red, has a crust of drying, soft consistency with characteristic the smell. Color of fat was light with a specific smell and has soft consistence. Tendons are soft, less dense, the surface of the joints is matt in some places. Likewise, the horsemeat from the zone of increased radiation risk displayed unevenly impregnated blood vessels, with the degree of exsanguination satisfactory. The part of pleura and peritoneum vessels were translucent, hypostases were absent, lymph nodes were hyperemic, swollen but not increased. The color of meat was red, there was a crust of drying, the meat is slightly wet which leaves a damp spot on the filter paper. Almost same pattern of characteristics was observed in horsemeat from the zone of increased radiation risk the state.

\section{Chemical Composition of Horsemeat in Case of Parascaridosis}

The difference in moisture, fat, ash and protein content compared to FAO data was observed and summarized in Table 2. For the minimum radiation risk zone the moisture content was $9.32 \mathrm{~g}$ higher and the protein content was $0.9 \mathrm{~g}$ higher as compared to FAO data. For the maximum radiation risk zone, the moisture content was $9 \mathrm{~g}$ higher and the protein content was $0.2 \mathrm{~g}$ higher. Likewise, for the radiation risk zone, the moisture content was $9 \mathrm{~g}$ higher, the protein content was $0.5 \mathrm{~g}$ higher and for the emergency radiation risk zone, the moisture content was $9.6 \mathrm{~g}$ higher and the protein content was $0.1 \mathrm{~g}$ lower as compared to FAO data.

In the zone of minimal radiation risk $\mathrm{pH}$ indicators were 5.74-6.0, reaction to peroxidase enzyme was positive and reaction to the enzyme with $5 \%$ solution of sulfuric copper broth was transparent. Formolic reaction was negative, extraction from meat looked transparent liquid indicating primary protein decomposition with 
transparent aromatic broth without impurities Bacterioscopy of fingerprints indicated no pathogenic microflora. Horsemeat samples from the zone of maximum radiation risk had negative indicators. $\mathrm{pH}$ in the muscular tissue of animals was 5.8-6.0. The reaction to peroxidase was negative and reactions with $\mathrm{CuSO}_{4}$ multiple broth indicated primary protein decomposition. Likewise, horsemeat from the zone of increased radiation risk also had negative indicators. $\mathrm{pH}$ in the muscular tissue of animals was 5.9-6.1. The reaction to peroxidase was positive. While reacting with $\mathrm{CuSO}_{4}$, the broth was turbid with formation of flakes and the broth acquired a gelatinous consistency. The formol test was positive indicating the primary protein decomposition. Samples of horsemeat taken from the zone of extreme radiation risk had negative indicators. $\mathrm{pH}$ in the muscular tissue of animals was increased and amounted to 6.2. The reaction to peroxidase was positive. The reaction with $\mathrm{CuSO}_{4}$-muddy broth, with the formation of flakes, the broth acquired a gelatinous consistency, the formol test was positive; the determination of primary protein decompositionmuddy broth with flakes.

Bacterioscopy of smears and horse prints from the zone of minimal radiation risk in the deep layers of muscles indicated no pathogenic microflora. Microflora of 15-20 Cocci and 8-14 Sticks were found in the horse from the zone of extreme radiation risk. Meat microflora from the zone of maximum radiation risk was 15-18 colonies of Cocci and 6-9 sticks. The number of coccasins in meat from the zone of high radiation risk was $8-12$, sticks $2-3$.

\section{Amino Acid Composition of Horsemeat in Case of Parascaridosis}

The analysis of amino acids composition is given in Table 3. The sum of amino acids in horsemeat from the zone of extreme radiation risk was $17966 \pm 0.5$ мг $\backslash 100 \mathrm{~g}$ of the product. The essential amino acids were $6974 \pm 0.7 \mathrm{mg} / 100 \mathrm{~g}$ of the product, replaceable amino acids were $10992 \pm 0.6 \mathrm{Mr} / 100 \mathrm{~g}$ of the product. The sum of amino acids in horsemeat from the maximum radiation risk zone was $18187 \pm 0.03 \mathrm{mg} / 100$ $\mathrm{g}$ of the product including essential amino acids $7014 \pm 0.8$ and essential amino acids $11173 \pm 0.08$ $\mathrm{Mr} / 100 \mathrm{~g}$ of the product. Likewise, the sum of amino acids in the equine of the increased radiation risk zone was $18343 \pm 0.05 \mathrm{mg} / 100 \mathrm{~g}$ of the product, including essential amino acids $7062 \pm 0.04 \mathrm{mg} / 100 \mathrm{~g}$ of the product and replaceable amino acids $11281 \pm 0.5$ $\mathrm{mg} / 100 \mathrm{~g}$ of the product. Further, the sum of amino acids in the equine of the minimum radiation risk zone was $18512 \pm 0.05 \mathrm{~g}$ of the product including $7183 \pm 0.04$ $\mathrm{g}$ of essential amino acids and $11329 \pm 0.4 \mathrm{~g}$ of essential amino acids.

\section{Fatty Acid Composition in Case of Parascaridosis}

The sum of fatty acids in the muscle tissue of horses from the zone of extreme radiation risk was $5.68 \mathrm{~g} / 100 \mathrm{~g}$, including: Saturated fatty acids (2.2 \pm 0.06$), \quad \mathrm{C}_{14: 0} \quad$ Myristinic $\quad(0.14 \pm 0.13), \quad \mathrm{C}_{16: 0}$ palmitinic (1.84 \pm 0.02$), \mathrm{C} 18: 0.22 \pm 0.05,0.22 \pm 0.05$, $2.70 \pm 0.01, \quad 0.24 \pm 0.77, \quad 0.02 \pm 0.23, \quad 0.02 \pm 0.23$, C18:1olein (2.44 \pm 0.03$)$, polyunsaturated fatty acids $(0.78 \pm 0.05) \mathrm{C}_{18: 2}$ linolein $(0.68 \pm 0.038), \mathrm{C}_{18: 3}$ linolenic $(0.10 \pm 0.09) \mathrm{g} / 100 \mathrm{~g}$ of the product (Table 4$)$.
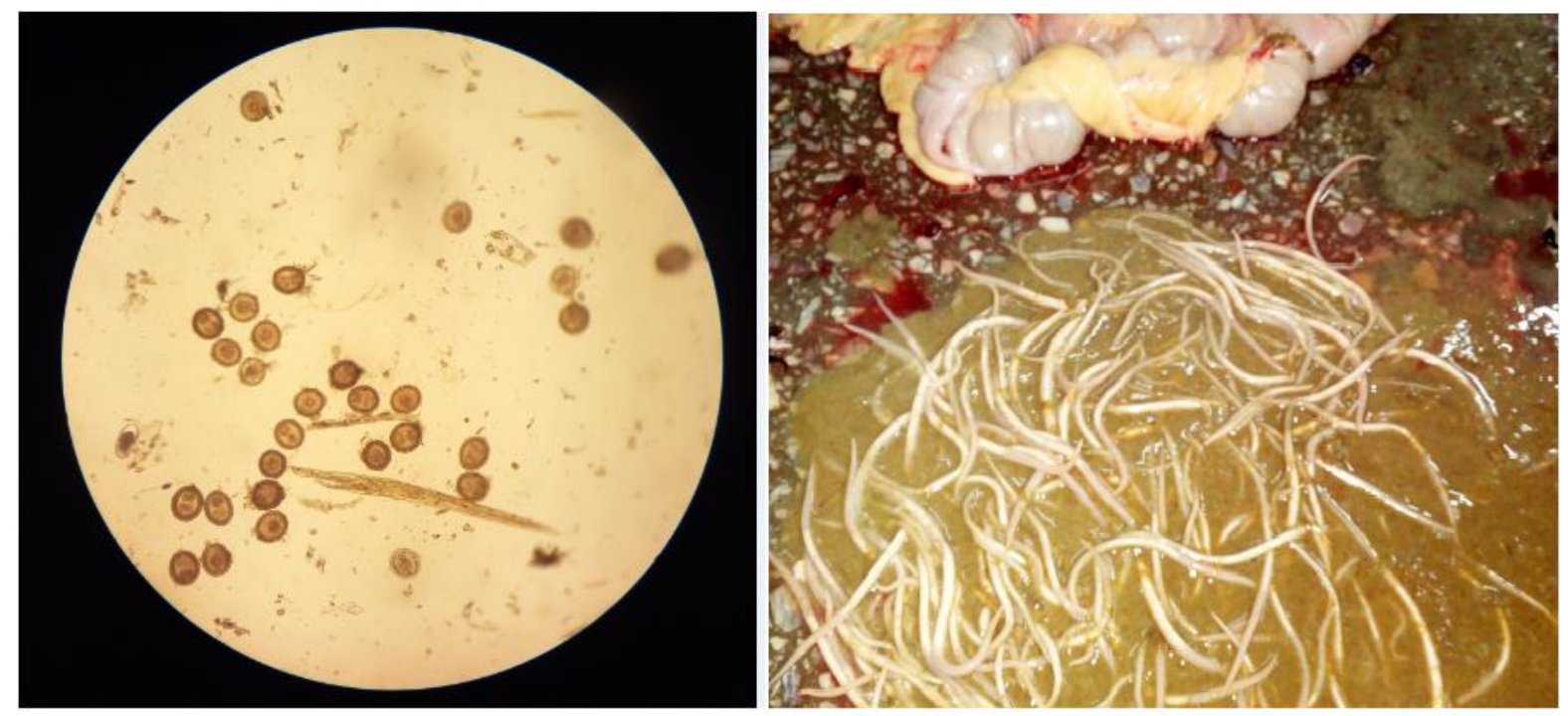

Fig. 1: The prevalence of parascaridosis in the tested horses 
Table 1: Radiometric values of samples in studied territories of variable risks

\begin{tabular}{|c|c|c|c|}
\hline \multirow[b]{2}{*}{ Radiometric values } & \multicolumn{3}{|l|}{ Zone } \\
\hline & $\begin{array}{l}\text { Zone of extreme } \\
\text { radiation risk }\end{array}$ & $\begin{array}{l}\text { Zone of maximum } \\
\text { radiation risk }\end{array}$ & $\begin{array}{l}\text { Zone of increased } \\
\text { radiation risk }\end{array}$ \\
\hline EDR level, $\mu \mathrm{Sv} / \mathrm{h}$ & 0.320 & 0.17 & 0.1400 \\
\hline The alpha-particle flux density, part/min $* \mathrm{~cm}^{2}$ & 3.200 & 1.30 & 0.5000 \\
\hline The beta-particles flow density, part $/ \mathrm{min}^{*} \mathrm{~cm}^{2}$ & 8.600 & 5.40 & 3.5000 \\
\hline \multicolumn{4}{|l|}{ Concentration of radionuclides in soil, $\mathrm{Bq} / \mathrm{kg}$} \\
\hline Am-241 & 18.600 & 6.00 & 1.3000 \\
\hline Cs-137 & 132.220 & 21.00 & 6.6000 \\
\hline $\mathrm{Pu}-239 / 240$ & 2.200 & 0.05 & 0.0200 \\
\hline \multicolumn{4}{|l|}{ Concentration of radionuclides in vegetation, $\mathrm{Bq} / \mathrm{kg}$} \\
\hline Am-241 & 1.800 & 1.50 & 0.5000 \\
\hline Cs-137 & 58.000 & 48.00 & 1.6000 \\
\hline $\mathrm{Pu}-239 / 240$ & 1.800 & 1.10 & 0.0500 \\
\hline \multicolumn{4}{|l|}{ Concentration of radionuclides in water, $\mathrm{Bq} / \mathrm{kg}$} \\
\hline Am-241 & 0.010 & 0.01 & 0.0100 \\
\hline Cs-137 & 2.000 & 0.10 & 0.0200 \\
\hline $\mathrm{Pu}-239 / 240$ & 0.050 & 0.03 & 0.0003 \\
\hline \multicolumn{4}{|l|}{ Concentration of radionuclides in meat, $\mathrm{Bq} / \mathrm{kg}$} \\
\hline Am-241 & 0.500 & nd & nd \\
\hline Cs-137 & 3.990 & nd & nd \\
\hline $\mathrm{Pu}-239 / 240$ & 0.056 & nd & nd \\
\hline
\end{tabular}
nd-not detected

Table 2: Chemical composition of horsemeat

\begin{tabular}{|c|c|c|c|c|}
\hline \multirow[b]{2}{*}{ Indicator } & \multicolumn{4}{|l|}{ Zones } \\
\hline & $\begin{array}{l}\text { Zone of extreme } \\
\text { radiation risk }(\%)\end{array}$ & $\begin{array}{l}\text { Zone of max. } \\
\text { radiation risk }(\%)\end{array}$ & $\begin{array}{l}\text { Zone of increased } \\
\text { radiation risk (\%) }\end{array}$ & $\begin{array}{l}\text { Zone of min. } \\
\text { radiation risk }(\%)\end{array}$ \\
\hline Moisture & $68.7-68.1$ & $65.8-679$ & $62.1-64.9$ & $63.4-64.4$ \\
\hline Fat & $16.8-17.2$ & $16.8-17.2$ & $15.4-16.7$ & $14.2-15.8$ \\
\hline Protein & $14.2-14.9$ & $14.5-15.8$ & $16.4-17.5$ & $17.5-18.7$ \\
\hline Ash & $0.91-0.93$ & $0.92-0.97$ & 0.94-1.09 & $1.01-1.15$ \\
\hline
\end{tabular}

Table 3: Amino acid composition of horsemeat (mg/100 g)

\begin{tabular}{|c|c|c|c|c|c|}
\hline \multirow[b]{2}{*}{ Amino acid } & \multirow[b]{2}{*}{ FAO scale } & \multicolumn{4}{|l|}{ Zones } \\
\hline & & $\begin{array}{l}\text { Zone of extreme } \\
\text { radiation risk }\end{array}$ & $\begin{array}{l}\text { Zone of max. } \\
\text { radiation risk }\end{array}$ & $\begin{array}{l}\text { Zone of increased } \\
\text { radiation risk }\end{array}$ & $\begin{array}{l}\text { Zone of min. } \\
\text { radiation risk }\end{array}$ \\
\hline Essential amino acids & 12027 & $6974 \pm 0.7$ & $7014 \pm 0.8$ & $7062 \pm 0.04$ & $7183 \pm 0.04$ \\
\hline Non-essential amino acids & 8917 & $10992 \pm 0.6$ & $11173 \pm 0.08$ & $11281 \pm 0.5$ & $11329 \pm 0.4$ \\
\hline Total & 20944 & $17966 \pm 0.5$ & $18187 \pm 0.03$ & $18343 \pm 0.05$ & $18512 \pm 0.05$ \\
\hline
\end{tabular}

Table 4: Fatty acid composition of horsemeat (g/100 g)

\begin{tabular}{|c|c|c|c|c|c|}
\hline \multirow[b]{2}{*}{ Fatty acids $(\mathrm{g} / 100 \mathrm{~g})$} & \multirow[b]{2}{*}{ FAO scale } & \multicolumn{4}{|l|}{ Zones } \\
\hline & & $\begin{array}{l}\text { Zone of extreme } \\
\text { radiation risk }\end{array}$ & $\begin{array}{l}\text { Zone of maximum } \\
\text { radiation risk }\end{array}$ & $\begin{array}{l}\text { Zone of increased } \\
\text { radiation risk }\end{array}$ & $\begin{array}{l}\text { Zone of minimum } \\
\text { radiation risk }\end{array}$ \\
\hline Saturated fatty acids & 2.81 & $2.2 \pm 0.06$ & $2.3 \pm 0.06$ & $2.51 \pm 0.04$ & $2.62 \pm 0.03$ \\
\hline $\mathrm{C}_{14: 0}$ myristinic & 0.27 & $0.14 \pm 0.13$ & $0.14 \pm 0.13$ & $0.25 \pm 0.04$ & $0.26 \pm 0.01$ \\
\hline $\mathrm{C}_{16: 0}$ palmitinic & 2.08 & $1.84 \pm 0.02$ & $1.84 \pm 0.02$ & $1.98 \pm 0.12$ & $2.04 \pm 0.04$ \\
\hline $\mathrm{C}_{18: 0}$ stearic & 0.35 & $0.22 \pm 0.05$ & $0.22 \pm 0.05$ & $0.28 \pm 0.05$ & $0.32 \pm 0.05$ \\
\hline Monounsaturated fatty acids & 3.79 & $2.70 \pm 0.01$ & $2.98 \pm 0.03$ & $3.5 \pm 0.01$ & $3.74 \pm 0.01$ \\
\hline $\mathrm{C}_{14: 1}$ myristolein & 0.06 & $0.24 \pm 0.77$ & $0.27 \pm 1.07$ & $0.26 \pm 0.77$ & $0.22 \pm 0.777$ \\
\hline $\mathrm{C}_{16: 1}$ palmitoleinic & 0.69 & $0.02 \pm 0.23$ & $0.02 \pm 0.25$ & $0.44 \pm 0.23$ & $0.62 \pm 0.23$ \\
\hline $\mathrm{C}_{18: 1}$ olein & 3.01 & $2.44 \pm 0.03$ & $2.69 \pm 0.03$ & $2.87 \pm 0.03$ & $2.90 \pm 0.03$ \\
\hline Polyunsaturated fatty acids & 1.24 & $0.78 \pm 0.05$ & $0.85 \pm 0.7$ & $0.90 \pm 0.04$ & $1.05 \pm 0.05$ \\
\hline $\mathrm{C}_{18: 2}$ linolein & 0.93 & $0.68 \pm 0.038$ & $0.74 \pm 0.058$ & $0.76 \pm 0.04$ & $0.89 \pm 0.04$ \\
\hline $\mathrm{C}_{18: 3}$ linolenic & 0.17 & $0.10 \pm 0.09$ & $0.11 \pm 0.09$ & $0.14 \pm 1.05$ & $0.16 \pm 0.06$ \\
\hline Total sum of amino acids & 15.4 & 5.68 & $6.2 \pm 0.06$ & $6.91 \pm 0.08$ & $7.41 \pm 0.02$ \\
\hline
\end{tabular}


In the muscle tissue of horses collected from the zone of maximum radiation risk, quantity of fatty acids was $6.2 \pm 0.06 \mathrm{~g} / 100 \mathrm{~g}$ including saturated fatty acids $(2.3 \pm 0.06), \quad \mathrm{C}_{14: 0}$ with myristinic acid $(0.14 \pm 0.13), \mathrm{C}_{16: 0}$ with palmitinic acid $(1.84 \pm 0.02)$, C18 (0.22 \pm 0.05$), 0.22 \pm 0.05,2.98 \pm 0.03,0.27 \pm 1.07$, $0.02 \pm 0.25, \quad 0.02 \pm 0.25, \quad \mathrm{C}_{18: 1} \quad$ olein $(2.69 \pm 0.03)$, polysaturated $(0.85 \pm 0.7), \mathrm{C}_{18: 2}$ linolein $(0.74 \pm 0.058)$, $\mathrm{C}_{18: 3}$ linolenic $(0.11 \pm 0.09) \mathrm{g} / 100 \mathrm{~g}$ of the product.

In the meat samples collected from the zone of increased radiation risk, the sum of fatty acids was $6.91 \pm 0.08 \mathrm{~g} / 100 \mathrm{~g}$, including saturated fatty acids (2.51 \pm 0.04$), \quad \mathrm{C}_{14: 0}$ myristinic acid $(0.25 \pm 0.04), \mathrm{C}_{16: 0}$ palmitinic acid (1.98 \pm 0.12$), \mathrm{C} 18: 0.28 \pm 0.05,0.28 \pm 0.05$, $3.5 \pm 0.01, \mathrm{C} 14: 1$ (0.26 \pm 0.77$) ; \mathrm{C} 16: 1$ (0.44 \pm 0.23$), \mathrm{C} 18: 1$ $2.87 \pm 0.03, \quad 0.90 \pm 0.04,0.28 \pm 0.05, \quad 0.76 \pm 0.0$ and $\mathrm{C} 18: 2$ $0.76 \pm 0.0, \mathrm{C} 18: 3(0.14 \pm 1.05) \mathrm{g} / 100 \mathrm{~g}$ of the product. Further, the total content of saturated fatty acids in the muscular tissue of horses from the zone of minimal radiation risk was $7.41 \pm 0.02$, including: saturated fatty acids (2.62 \pm 0.03$), \quad \mathrm{C}_{14: 0}$ myristinic $(0.26 \pm 0.01), \mathrm{C}_{16: 0}$ palmitin $\quad(2.04 \pm 0.04), \quad \mathrm{C}_{18: 0} \quad$ stearin $(0.32 \pm 0.05)$ monosaturated $(3.74 \pm 0.01), \mathrm{C}_{14: 1}$ myristolein $(0.22 \pm 0.777)$ $\mathrm{C}_{16: 1}$ palmitolein $(0.62 \pm 0.23), \mathrm{C}_{18: 1}$ olein $(2.90 \pm 0.03)$, polysaturated $(1.05 \pm 0.05), \mathrm{C} 18: 2$ linolein $(0.89 \pm 0.04)$ C18:3 linolenic $(0.16 \pm 0.06) \mathrm{g} / 100 \mathrm{~g}$ of the product.

\section{Vitamins Composition of Horsemeat in Case of Parascaridosis}

Vitamins composition of the meat samples collected from various risk zones is summarized in Table 5. In horsemeat from the zone of extreme radiation risk, the vitamin $\mathrm{E}$ content was less than the norm by $20-25 \%$, vitamin PP by $27-28 \%$, vitamin B1 by $36-36 \%$ and vitamin B2 by $40-60 \%$. In horsemeat from the zone of maximum radiation risk, the vitamin $\mathrm{E}$ content was found to be $13.4-14.4 \%$ less, vitamin PP by $23-25.4 \%$, vitamin B1 by $25.8-36 \%$, vitamin B2 by $40-50 \%$ than the normal standard ranges. Whereas, the horsemeat collected from the zone of increased radiation risk, exhibited vitamin $\mathrm{E}$, vitamin $\mathrm{PP}$, vitamin $\mathrm{B} 1$, vitamin $\mathrm{B} 2$ contents as low as $12.2-13.5,11.7-12.7,11.7-12.7,11.5-15.8$ and $20-30 \%$ less than the norm values. Further, in horsemeat from the zone of minimum radiation risk of vitamin $\mathrm{E}$ was 7.7-9.3\% lower than the norm, vitamin PP is $10.4-13 \%$ lower, vitamin B1 is $11.5-12.9 \%$ lower and vitamin B2 is $20-30 \%$ lower than standard range. All these results indicate that vitamins content of the horsemeat from all zone of radiation risks were significantly compromised and thus need more widespread studies.

\section{The Mineral Composition of Horsemeat in Case of Parascaridosis}

The results regarding composition of microelements as Iron $(\mathrm{Fe})$, Copper $(\mathrm{Cu})$, Zinc $(\mathrm{Zn})$ is summarized in Table 6. In meat from the zone of extreme radiation risk, the iron content was $2705-2712 \mu \mathrm{g} / 100 \mathrm{~g}$, copper from $178-183 \mu \mathrm{g} / 100 \mathrm{~g}$ and zinc content from 27.7-28.7 $\mu \mathrm{g} / 100 \mathrm{~g}$. The values of these essential minerals were low than FAO scale (Table 6) and were as low as 12.6-12.8, 11.2-15.6 and 7.5-10.7\% respectively.

In the zone of maximum radiation risk the content of iron was 2897-2914 $\mu \mathrm{g} / 100 \mathrm{~g}$; copper from 187-190 $\mu \mathrm{g} / 100 \mathrm{~g}$; zinc from 29.1-29.2 $\mu \mathrm{g} / 100 \mathrm{~g}$, which were less than the normal ranges by $6-6.6,7.8-9.3$ and $5.9-6.2 \%$ respectively. In the zone of increased radiation risk the content of iron was 2905-3012 $\mu \mathrm{g} / 100 \mathrm{~g}$, copper content was from 191-195 $\mu \mathrm{g} / 100 \mathrm{~g}$ and zinc from 28.9-29.5 $\mu \mathrm{g} / 100 \mathrm{~g}$ which were less from the normal ranges by 2.9 $6.3,5.4-7.2$ and $4.9-6.8 \%$ for these minerals respectively. Further, in the zone of minimum radiation risk, the iron content was 2902-2975 $\mu \mathrm{g} / 100 \mathrm{~g}$, copper 186-190 $\mu \mathrm{g} / 100$ $\mathrm{g}$, zinc from $29.3-29.4 \mu \mathrm{g} / 100 \mathrm{~g}$ which were again less from the normal ranges by $\mathrm{r} 4.1-6.4,5.2-6.8$ and $5.2-5.5 \%$ respectively. Our finding suggests that essential minerals contents were quiet low in meat from various radiation risks and further necessary actions are required.

Table 5: Vitamin composition of horsemeat sampled from different zones of radiation risk

\begin{tabular}{|c|c|c|c|c|c|}
\hline \multirow[b]{2}{*}{ Vitamins composition } & \multirow[b]{2}{*}{ FAO scale } & \multicolumn{4}{|l|}{ Zones } \\
\hline & & $\begin{array}{l}\text { Zone of extreme } \\
\text { radiation risk }\end{array}$ & $\begin{array}{l}\text { Zone of maximum } \\
\text { radiation risk }\end{array}$ & $\begin{array}{l}\text { Zone of increased } \\
\text { radiation risk }\end{array}$ & $\begin{array}{l}\text { Zone of minimum } \\
\text { radiation risk }\end{array}$ \\
\hline Vitamin E (mg) & 0.80 & $0.6-0.64$ & $0.68-0.69$ & $0.69-0.7$ & $0.72-0.73$ \\
\hline Vitamin PP(mg) & 3.00 & $2.16-2.19$ & $2.23-2.31$ & $2.61-2.64$ & $2.61-2.68$ \\
\hline Vitamin $B_{1}(\mathrm{mg})$ & 0.07 & $0.03-0.04$ & $0.04-0.05$ & $0.05-0.06$ & $0.06-0.061$ \\
\hline Vitamin $B_{2}(\mathrm{mg})$ & 0.10 & $0.04-0.06$ & $0.05-0.06$ & $0.07-0.08$ & $0.07-0.09$ \\
\hline
\end{tabular}

Table 6: Mineral composition of horsemeat, $\mu \mathrm{g} / 100 \mathrm{~g}$

\begin{tabular}{llllll}
\hline & & Zones & & \\
& & - & & \\
Mineral & FAO scale & $\begin{array}{l}\text { Zone of extreme } \\
\text { radiation risk }\end{array}$ & $\begin{array}{l}\text { Zone of maximum } \\
\text { radiation risk }\end{array}$ & $\begin{array}{l}\text { Zone of increased } \\
\text { radiation risk }\end{array}$ & $\begin{array}{l}\text { Zone of minimum } \\
\text { radiation risk }\end{array}$ \\
\hline Iron $(\mathrm{Fe})$ & 3100 & $2705-2712$ & $2897-2914$ & $2905-3012$ & $2902-2975$ \\
Copper $(\mathrm{Cu})$ & 206 & $178-183$ & $187-190$ & $191-195$ & $296-190$ \\
Zinc $(\mathrm{Zn})$ & 31 & $27.7-28.7$ & $29.1-29.2$ & $28.9-29.5$ & 29.4 \\
\hline
\end{tabular}




\section{Conclusion}

Thus, the results of the studies showed a difference in the biological value of the horse, depending on the sampling location and distance from the territory of the former SNTS. Organoleptic characteristics of horsemeat in different radiation risk zones showed no particular differences. It was noted that the content of amino acids, fatty acids, vitamins and minerals decreased in horsemeat samples taken closer to the SNTS area. This is due to the fact that ionizing radiation exposure in affected doses causes a decrease in the productivity of farm animals and a worsening the quality of animal products. The low contents of essential minerals and vitamins can be attributed to the presence of Parascaridosis as well as radiations effects. Further, detailed studies are warranted for more generalization of the current findings.

\section{Acknowledgement}

The authors would like to thank the staff of the engineering laboratory "Scientific Center of Radioecological Research" of Shakarim University in Semey for conducting the analysis.

\section{Author's Contributions}

Shyngys Suleimenov: Designed the study, developed the methodology, performed the analysis and wrote the manuscript, performed the chemical and nutritive composition determinations.

Sergazy Duyssembaev and Ainur Serikova: Designed the study, developed the methodology, performed the analysis and wrote the manuscript.

Abdrakhman Baygazanov: Provided helpful feedback on an early draft of the paper.

Ainur Koygeldinova: Performed the chemical and nutritive composition.

Zhanibek Yessimbekov: Assisted with data analysis.

\section{Ethics}

This article is original and contains unpublished material. The corresponding author confirms that all of the other authors have read and approved the manuscript and no ethical issues involved.

\section{References}

Belaunzaran, X., Bessa, R. J., Lavín, P., Mantecón, A. R., Kramer, J. K., \& Aldai, N. (2015). Horse-meat for human consumption-Current research and future opportunities. Meat Science, 108, 74-81.

Berezovsky, A. V., \& Galat, M. V. (2008). Helminthoses of single-hoofed animals in Ukraine. In Materials of the Ill scientific and practical conference of the International Association of Parasitologists, Vitebsk, pp. 26-27.
Demidchik, L. G. (2001). Anthelminthic efficiency of fenacure at parascariasis and strongylatosis of gastrointestinal tract of horses. Veterinarnaya meditsina, 599-599.

Duyssembaev, S., Serikova, A., Iminova, D., Omargalieva, N., Serikov, Z., Koigeldinova, A., \& Kassenov, K. (2016). Organoleptic indicators and chemical composition of horse meat. Research Journal of Pharmaceutical, Biological and Chemical Sciences, 7(5), 2444-2448.

GOST 23392-2016. (2016). "Meat. Methods for chemical and microscopic analysis of freshness". Inter-Governmental Council on Standardization, Metrology and Certification. http://docs.cntd.ru/document/1200144232

GOST 26305-84. (1984). "Sealed radionuclidic alpharadiation sources. Method of parameters measurement", USSR Gosstandart. http://docs.cntd.ru/document/gost-26305-84

GOST 26306-84. (1984). "Sealed radionuclidic betaradiation sources. Methods of parameters measurement", USSR Gosstandart. http://docs.cntd.ru/document/1200015358

GOST 26307-84. (1984). "Sealed radionuclidic gammaradiation sources. Methods of parameters measurement", USSR Gosstandart. http://docs.cntd.ru/document/gost-26307-84

GOST 26931-86. (1986). "Raw materials and food products. Method for determination of copper", USSR National Committee on Standards. http://docs.cntd.ru/document/1200021126

GOST 26934-86. (1986). "Raw materials and food products. Method for determination of zinc", USSR National Committee on Standards. http://docs.cntd.ru/document/1200021133

GOST 7269-79. (1979). "Sampling methods and organoleptic methods for determining freshness". USSR National Committee on Standards. http://docs.cntd.ru/document/1200021593

GOST 9959-91. (1991). "Meat products. Common conditions of organoleptical assessment". USSR Committee on Standardization and Metrology. http://docs.cntd.ru/document/1200021615

Grosche, B. (2002). Semipalatinsk test site: Introduction. Radiation and environmental biophysics, 41(1), 53-55.

Grosche, B., Zhunussova, T., Apsalikov, K., \& Kesminiene, A. (2015). Studies of health effects from nuclear testing near the Semipalatinsk Nuclear Test Site, Kazakhstan. Central Asian journal of global health, 4(1).

Kakimov, A., Yessimbekov, Z., Kakimova, Z., Bepeyeva, A., \& Stuart, M. (2016). Cs-137 in milk, vegetation, soil and water near the former Soviet Union's Semipalatinsk Nuclear Test Site. Environmental Science and Pollution Research, 23(5), 4931-4937. 
Lebedev, P. T., \& Usovich, A. T. (1976). Research methods for animal feed, organs and tissues. M.: Rosselkhozizdat, 376.

Lee, C. E., Seong, P. N., Oh, W. Y., Ko, M. S., Kim, K. I., \& Jeong, J. H. (2007). Nutritional characteristics of horsemeat in comparison with those of beef and pork. Nutrition research and practice, 1(1), 70.

Levine, M. B., Smith, E. D., Sharples, F. E., \& Eddlemon, G. K. (1990). Integrating NEPA (National Environmental Policy Act) and CERCLA (Comprehensive Environmental Response, Compensation and Liability Act) requirements during remedial responses at DOE facilities (No. ORNL/TM11564). Oak Ridge National Lab., TN (USA).

Logachev, V. A. (2000). Nuclear test at Semipalatinsk test site and their environmental impacts. Vestnik Natsional'nogo Yadernogo Tsentra Respubliki Kazakhstan, 3(4), 9-14.

Lorenzo, J. M., Sarriés, M. V., Tateo, A., Polidori, P., Franco, D., \& Lanza, M. (2014). Carcass characteristics, meat quality and nutritional value of horsemeat: A review. Meat Science, 96(4), 1478-1488.

Miller, F. L., Bellaw, J. L., Lyons, E. T., \& Nielsen, M. K. (2017). Strongyloides westeri worm and egg counts in naturally infected young horses. Veterinary parasitology, 248, 1-3.
Ponomarev, N. M. (1997). Experience of using "Pour on" preparations of duotin and willowworm in parascariasis and gastrointestinal strongylatosis of horses. In: Associative Infections of Agricultural Animals and New Approaches to Their Elimination and Prevention. https://www.elibrary.ru/item.asp?id=34921435

Purvis-Roberts, K. L., Werner, C. A., \& Frank, I. (2007). Perceived risks from radiation and nuclear testing near Semipalatinsk, Kazakhstan: A comparison between physicians, scientists and the public. Risk Analysis: An International Journal, 27(2), 291-302.

Sidorkin, V. A. (2007). Horse parascariasis in Saratov region. Veterinarnaya meditsina, 5, 28-32.

Suleimenov, S. K., Dyusembayev, S. T., Zabolotnykh, M. V., \& Gabdullin, D. E. (2019). Veterinarysanitary indicators of parascaridosis in horses living in the territory of Semipalatinsk Test Site. Science and education, 57, 170-175.

Zhumadilov, K., Ivannikov, A., Stepanenko, V., Zharlyganova, D., Toyoda, S., Zhumadilov, Z., \& Hoshi, M. (2013). ESR dosimetry study of population in the vicinity of the Semipalatinsk Nuclear Test Site. Journal of radiation research, 54(4), 775-779.

Zotova, M. I. (2011). Investigation of horse faeces at the racetrack "Akbuzat". In Materials of the V AllRussian Student Scientific Conference. Ufa, p. 73. https://www.elibrary.ru/item.asp?id=25102708 